\title{
Pencegahan Kejadian Ventilator-Associated Pneumonia (VAP) dengan Kepatuhan Pelaksanaan Bundle: Literature Review
}

\author{
Solikin ${ }^{*}$, Matius Sakundarno Adi2, Septo Pawelas Arso²
}

1Program Studi Magister Kesehatan Masyarakat-Konsentrasi Administrasi Rumah Sakit, Fakultas Kesehatan Masyarakat Universitas Diponegoro/RSUP Dr. Kariadi Semarang, Indonesia.

*Email: solikin_karyadi@yahoo.com

2Program Studi Magister Kesehatan Masyarakat, Fakultas Kesehatan Masyarakat Universitas Diponegoro, Semarang, Indonesia

\section{Abstract \\ Prevention of Ventilator-Associated Pneumonia (VAP) Events with Compliance with Bundle Implementation: Literature Review}

Background: Patients who experience critical illness and use a mechanical ventilator in the ICU have an increased risk of experiencing ventilator associated pneumonia (VAP) which is a major cause of morbidity and mortality in the ICU and causes lengthening the length of stay and an increase in hospital costs.

Purpose: To conduct a recent literature review with regard to VAP primarily related to causes, risk factors, pathogenesis, prevention, early detection and diagnosis, and administration of antibiotics to patients with VAP. At the end of this article conclusions will be presented that can be used by practitioners as a clinical guide.

Method: The design used was literature review, articles were collected using a search engine, including (Clinicalkey) 27 articles, (Cochrane) 25 articles, (Medline) 17 articles and (Pubmed) 19 articles. From the predetermined article inclusion criteria, we found 7 articles out of 88 that were suitable for different interventions

Results: Prevention of VAP incidents in hospitals using multimodal interventions, one of which is the application of a VAP prevention bundle, can effectively reduce the incidence of VAP in hospitals. Examination of the lower respiratory tract culture should be carried out for all patients before administering antibiotic therapy provided that it should not delay giving antibiotic therapy to critical patients. Early treatment of broad-spectrum antibiotics with the right dosage can maximize the efficacy of antibiotics and the outcome of VAP patients in the ICU. Antibiotic combinations must be used wisely to treat VAP because certain pathogens increase the life expectancy of patients with severe infections especially those with septic shock. Negative culture results can also be used to stop antibiotic therapy in patients undergoing culture without antibiotic changes within the last 72 hours. The health team must consider the need for antibiotic de-escalation based on the culture results and the clinical response of the patient.

Conclusion: VAP prevention bundles that implement multimodal interventions effectively reduce the incidence of VAP in hospitals. An examination of airway culture must be carried out for all patients before administering antibiotic therapy. Early treatment of broad-spectrum antibiotics can maximize the efficacy of antibiotics and the outcome of VAP patients in the ICU.

\section{Keywords: VAP; ICU; Patients; Morbidity; Mortality; Bundle}

Pendahuluan: Pasien yang mengalami penyakit kritis dan menggunakan ventilator mekanik di ICU mempunyai peningkatan resiko untuk mengalami ventilator associated pneumonia (VAP) yang merupakan penyebab utama morbiditas dan mortalitas di ICU serta menyebabkan pemanjangan lenght of stay dan peningkatan biaya rumah sakit.

Tujuan: Untuk melakukan review literature terkini sehubungan dengan VAP terutama terkait dengan penyebab, faktor resiko, pathogenesis, pencegahan, deteksi dini dan diagnosis, serta pemberian antibiotik pada pasien dengan VAP. Di ahir artikel ini akan disampaikan kesimpulan yang dapat digunakan praktisi sebagai panduan di klinis.

Metode: Desain yang digunakan adalah literature review, artikel dikumpulkan menggunakan mesin pencarian antara lain (Clinicalkey) 27 artikel, (Cochrane) 25 artikel, (Medline) 17 artikel dan (Pubmed) 19 artikel. Dari kriteria inklusi artikel yang telah ditentukan, ditemukan 7 artikel dari 88 yang sesuai dengan intervensi yang berbeda. 
Hasil: Pencegahan kejadian VAP di rumah sakit menggunakan intervensi multimodal, yang mana salah satunya berupa penerapan bundle pencegahan VAP, dapat dengan efektif menurunkan kejadian VAP di rumah sakit. Pemeriksasan kultur saluran nafas bawah perlu dilakukan kepada semua pasien sebelum pemberian terapi antibiotik dengan catatan tidak boleh menunda pemberian terapi antibiotik pada pasien kritis. Terapi dini antibiotik spektum luas dengan dosis yang tepat dapat memaksimalkan kemanjuran antibiotik dan luaran pasien VAP di ICU. Kombinasi antibiotik harus digunakan dengan bijaksana untuk mengobati VAP karena pathogen tertentu untuk meningkatkan harapan hidup pasien dengan infeksi berat terutama yang mengalami shok sepsis. Hasil kultur yang negatif juga dapat digunakan untuk menghentikan terapi antibiotik pada pasien yang dilakukan kultur tanpa perubahan antibiotik dalam 72 jam terahir. Tim kesehatan harus mempertimbangkan perlunya deeskalasi antibiotik berdasarkan hasil kultur dan respon klinik pasien.

Simpulan: Bundle pencegahan VAP yang menerapkan intervensi multimodal efektif menurunkan kejadian VAP di rumah sakit. Pemeriksasan kultur saluran nafas harus dilakukan kepada semua pasien sebelum pemberian terapi antibiotik. Terapi dini antibiotik spektum luas dapat memaksimalkan kemanjuran antibiotik dan luaran pasien VAP di ICU.

\section{Kata Kunci: VAP; Pasien; ICU; Morbiditas; Mortalitas; Bundle}

\section{PENDAHULUAN}

Pasien yang mengalami penyakit kritis sering memerlukan alat untuk membantu mempertahankan pernafasan(Wang et al., 2016). Salah satu efek samping dari penggunaan alat ini adalah peningkatan resiko pneumonia yang disebut sebagai VAP (Wang et al., 2016). Terminologi ini merujuk kepada pneumonia yang terjadi pada setting ventilasi mekanik (Sebastian et al., 2012) yang mana muncul lebih dari 48 jam setelah intubasi endotracheal (ET) (Tablan et al., 2004). VAP merupakan salah satu infeksi nosocomial yang paling sering dialami oleh pasien (Lee et al., 2017; Silva et al., 2018) terutama bayi dengan berat badan rendah yang terpasang ventilator (Lee et al., 2017). VAP merupakan penyebab utama morbiditas dan mortalitas di ICU dan menyebabkan pemanjangan lenght of stay di rumah sakit dan ICU dan meningkatkan biaya rumah sakit (Alp \& Voss, 2006). Sangat sulit untuk mengetahui insiden yang sebenarnya dari VAP karena terdapat tumpang tindih dengan infeksi saluran bawah lainnya, seperti tracheobronchitis, terutama pada pasien dengan ventilasi mekanik (The American Thoracic Society \& The Infectious Diseases Society of America, 2005). Insiden VAP bervariasi dari $7 \%$ hingga $70 \%$ pada beberapa studi dan mortalitas berkisar 20\% hingga 75\% (Alp \& Voss, 2006). Insiden berkisar 6 sampai 20 kali lebih besar pada pasien yang terpasang ventilator (The American Thoracic Society \& The Infectious Diseases Society of America, 2005) atau sekitar $86 \%$ dari kejadian pneumonia nosocomial
(Sebastian et al., 2012). Artikel berikut ini akan memaparkan ulasan literatur terkait dengan penyebab, faktor resiko, pathogenesis, pencegahan, deteksi dini dan diagnosis, serta pemberian antibiotik pada pasien dengan VAP. Di ahir artikel ini akan disampaikan kesimpulan yang dapat digunakan praktisi sebagai panduan di klinis.

\section{METODE PENELITIAN}

Literature review studi dengan cara mengumpulkan sejumlah artikel melalui web dengan mesin pencarian antara lain (Clinicalkey) didapatkan 27 artikel, (Cochrane) 25 artikel, (Medline) 17 artikel dan (Pubmed) 19 artikel. Dari 88 artikel yang didapatkan dan disaring dengan kriteria inklusi yang telah ditentukan, ditemukan 7 artikel yang sesuai dengan intervensi yang berbeda.

Solikin' Program Studi Magister Kesehatan Masyarakat-Konsentrasi Administrasi Rumah Sakit, Fakultas Kesehatan Masyarakat Universitas Diponegoro/RSUP Dr. Kariadi Semarang, Indonesia *Email: solikin_karyadi@yahoo.com

Matius Sakundarno $\mathrm{Adi}^{2}$, Septo Pawelas Arso' ${ }^{2}$, Program Studi Magister Kesehatan Masyarakat, Fakultas Kesehatan Masyarakat Universitas Diponegoro, Semarang, Indonesia 


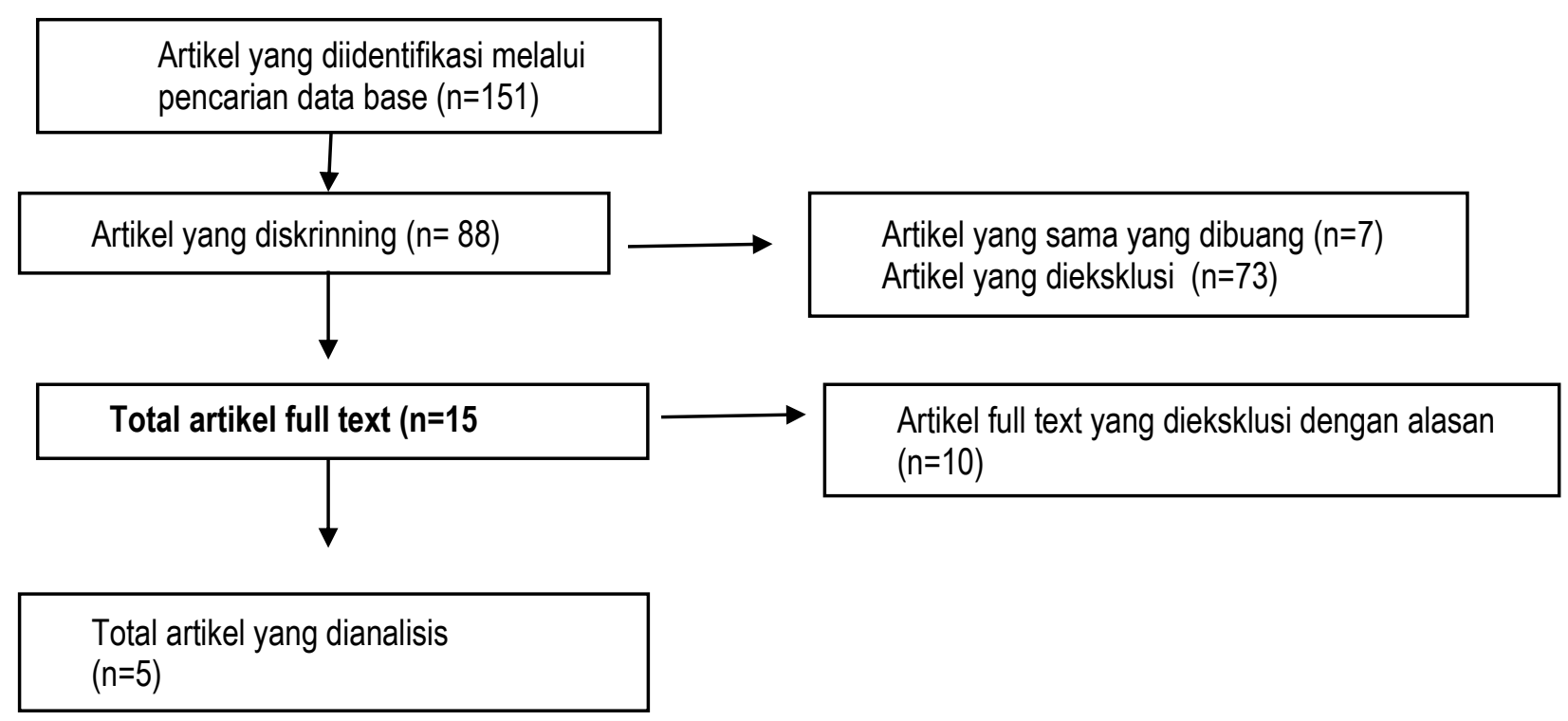

Gambar 1. PRISMA Flow Diagram dalam menseleksi artikel

Solikin' Program Studi Magister Kesehatan Masyarakat-Konsentrasi Administrasi Rumah Sakit, Fakultas Kesehatan Masyarakat Universitas Diponegoro/RSUP Dr. Kariadi Semarang, Indonesia *Email: solikin_karyadi@yahoo.com Matius Sakundarno $\mathrm{Adi}^{2}$, Septo Pawelas Arso', Program Studi Magister Kesehatan Masyarakat, Fakultas Kesehatan Masyarakat Universitas Diponegoro, Semarang, Indonesia 


\section{Tabel 1. Hasil Penelitian}

\begin{tabular}{|c|c|c|c|c|c|c|}
\hline Penulis/Judul & Tujuan dan Metode & Tempat dan Sampel & Instrumen & Perlakuan & Hasil & Simpulan \\
\hline $\begin{array}{l}\text { Ramadhan, H. N. } \\
\text { (2019).Pelaksanaan } \\
\text { Pencegahan dan } \\
\text { Pengendalian } \\
\text { Ventilator Associated } \\
\text { Pneumonia (VAP) di } \\
\text { Ruang ICU. The } \\
\text { Journal of Hospital } \\
\text { Accreditation, 1(1). }\end{array}$ & $\begin{array}{l}\text { - Mengeksplorasi } \\
\text { pelaksanaan, } \\
\text { pencegahan dan } \\
\text { pengendalian } \\
\text { VAP } \\
\text { - Wawancara } \\
\text { mendalam, } \\
\text { observasi, dan } \\
\text { telaah dokumen. } \\
\text { - Analisis dilakukan } \\
\text { dengan content } \\
\text { analysis }\end{array}$ & $\begin{array}{l}\text { - Di ruang ICU, RSUP } \\
\text { Dr. Kariadi } \\
\text { Semarang } \\
\text { - Memilih } 12 \text { informan } \\
\text { dan berdasarkan } \\
\text { prinsip kesesuaian } \\
\text { (appropriateness) } \\
\text { dan kecukupan } \\
\text { (adequacy) dengan } \\
\text { kriteria mengetahui } \\
\text { dan atau terlibat } \\
\text { langsung dalam } \\
\text { pencegahan dan } \\
\text { pengendalian VAP }\end{array}$ & $\begin{array}{l}\text { Menggunakan teori } \\
\text { Edward III, yaitu } \\
\text { bagaimana faktor } \\
\text { komunikasi, sumber } \\
\text { daya, disposisi, dan } \\
\text { struktur birokrasi } \\
\text { mempengaruhi } \\
\text { pelaksanaan } \\
\text { Standard Operating } \\
\text { Procedures } \\
\text { (SOP) VAP bundle } \\
\text { sebagai pedoman } \\
\text { pencegahan dan } \\
\text { pengendalian VAP }\end{array}$ & $\begin{array}{l}\text { Data hasil rekaman suara } \\
\text { dengan format digital } \\
\text { dituangkan dalam bentuk } \\
\text { tulisan transkrip wawancara, } \\
\text { yang kemudian } \\
\text { disederhanakan dalam bentuk } \\
\text { matriks sesuai dengan poin } \\
\text { pertanyaan serta } \\
\text { dikompilasikan dengan data } \\
\text { yang didapatkan. dari hasil } \\
\text { observasi dan telaah dokumen } \\
\text { untuk dianalisis dengan metode } \\
\text { content analysis (analisis isi), } \\
\text { untuk } \\
\text { mendapatkan hasil secara } \\
\text { obyektif, sistematis, dan } \\
\text { mempunyai referensi teoritis. } \\
\text { Etika penelitian menggunakan } \\
\text { informed consent yang } \\
\text { diberikan kepada informan } \\
\text { sebelum peneliti mengambil } \\
\text { data primer, serta melakukan } \\
\text { perizinan kepada informan } \\
\text { untuk diambil rekaman selama } \\
\text { peneliti melakukan } \\
\text { pengumpulan data. }\end{array}$ & $\begin{array}{l}\text { Pelaksanaan pencegahan dan } \\
\text { pengendalian VAP di ruang ICU, } \\
\text { RSUP Dr. Kariadi Semarang } \\
\text { mengacu pada } \\
\text { Permenkes } 27 / 2017 \text { dengan } \\
\text { beberapa inovasi dan penyesuaian. } \\
\text { Komunikasi terkait pelaksanaan } \\
\text { VAP bundle di ruang ICU berjalan } \\
\text { dengan baik, perawat diberi } \\
\text { kesempatan untuk memperbarui } \\
\text { dan penyegaran ilmu, fasilitas } \\
\text { sangat mendukung, serta } \\
\text { koordinasi antar profesi berjalan } \\
\text { lancar. Adanya SOP, daftar } \\
\text { centang kepatuhan pelaksanaan } \\
\text { VAP bundle, serta lomba yang } \\
\text { sering diadakan dalam rangka } \\
\text { pencegahan dan pengendalian } \\
\text { infeksi mendorong pelaksana untuk } \\
\text { terus memperbaiki diri. } \\
\text { Walaupun demikian, masih } \\
\text { diperlukan pengingat untuk } \\
\text { melaksanakan VAP bundle sesuai } \\
\text { dengan SOP, yaitu oral hygiene } \\
\text { setiap } 8 \text { jam sekali. }\end{array}$ & $\begin{array}{l}\text { Pelaksanaan pencegahan dan } \\
\text { pengendalian VAP di Ruang ICU, RSUP } \\
\text { Dr. Kariadi Semarang tahun } 2018 \text { perlu } \\
\text { dipertahankan bahkan ditingkatkan. } \\
\text { Review mingguan dan penghargaan bagi } \\
\text { pelaksana diperlukan sebagai pendorong } \\
\text { untuk } \\
\text { terus melaksanakan VAP bundle sesuai } \\
\text { dengan SOP. }\end{array}$ \\
\hline
\end{tabular}

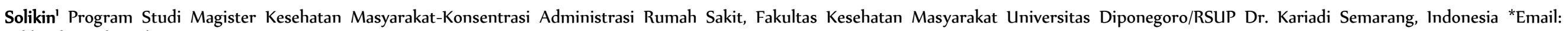
solikin_karyadi@yahoo.com

Matius Sakundarno Adi $^{2}$, Septo Pawelas Arso' ${ }^{2}$, Program Studi Magister Kesehatan Masyarakat, Fakultas Kesehatan Masyarakat Universitas Diponegoro, Semarang, Indonesia 
Pencegahan Kejadian Ventilator-Associated Pneumonia (VAP) dengan Kepatuhan Pelaksanaan Bundle: Literature review

\begin{tabular}{|c|c|c|c|c|c|c|}
\hline $\begin{array}{l}\text { Susmiarti, D., } \\
\text { Harmayetty, H., \& } \\
\text { Dewi, Y. S. (2015). } \\
\text { The Incidence of VAP } \\
\text { after VAP Bundle } \\
\text { Intervention Among } \\
\text { Patients with } \\
\text { Mechanical } \\
\text { Ventilation. Jurnal } \\
\text { Ners, 10(1), 138-146. }\end{array}$ & $\begin{array}{l}\text { - Tujuan: untuk } \\
\text { mengetahui } \\
\text { kejadian VAP } \\
\text { setelah diberikan } \\
\text { penerapan VAP } \\
\text { bundle } \\
\text { - Metode: One shot } \\
\text { case study post } \\
\text { test only. Dengan } \\
\text { teknik purposive } \\
\text { sampling. }\end{array}$ & $\begin{array}{l}\text { - Lokasi: Rumah Sakit } \\
\text { Angkatan Laut Dr. } \\
\text { Ramelan Surabaya } \\
\text { - Sampel sebanyak } 6 \\
\text { orang mulai } 31 \\
\text { Desember } 2013 \\
\text { sampai dengan } 31 \\
\text { Januari 2014: } \\
\text { 1)Pasien dengan } \\
\text { ETT yang } \\
\text { menggunakan } \\
\text { ventilator mekanik } \\
\text { mulai hari ke 0; 2) } \\
\text { Pasien adalah } \\
\text { berusia dewasa > } \\
\text { 18th; 3) Pasien yang } \\
\text { tidak terdiagnosa } \\
\text { pneumonia saat } \\
\text { masuk ICU; 4) } \\
\text { Pasien mendapatkan } \\
\text { Antibiotika }\end{array}$ & $\begin{array}{l}\text { - Alat ukur untuk } \\
\text { penerapan VAP } \\
\text { bundle berupa } \\
\text { lembar observasi } \\
\text { - sedangkan untuk } \\
\text { kejadian VAP } \\
\text { diukur melalui } \\
\text { lembar } \\
\text { monitoring } \\
\text { Clinical } \\
\text { Pulmonary } \\
\text { Infection Score } \\
\text { (CPIS). } \\
\text { Pemberian VAP } \\
\text { bundle pada } \\
\text { penelitian ini } \\
\text { dimulai setelah } \\
\text { responden } \\
\text { terpasang } \\
\text { ventilasi mekanis } \\
\text { yaitu pada hari ke } \\
\text { 0 sampai dengan } \\
\text { hari ke } 3\end{array}$ & $\begin{array}{l}\text { Setiap } \\
\text { pelaksanaan pemberian VAP } \\
\text { bundle dicatat } \\
\text { pada checklist monitoring VAP } \\
\text { bundle. Setelah } \\
\text { penerapan VAP bundle } \\
\text { kemudian pada hari ke } \\
3 \text { dilakukan penilaian kejadian } \\
\text { VAP melalui } \\
\text { monitoring clinical pulmonary } \\
\text { infection score } \\
\text { (CPIS) dengan mengumpulkan } \\
\text { data hasil } \\
\text { pemeriksaan suhu, leukosit, } \\
\text { sputum, PaO2/ } \\
\text { FiO2, Foto toraks, dan kultur } \\
\text { sputum responden } \\
\text { dan memasukkan data-data } \\
\text { tersebut ke dalam } \\
\text { lembar monitoring CPIS. } \\
\text { Keseluruhan datadata } \\
\text { tersebut di jumlah berdasarkan } \\
\text { kriteria } \\
\text { yang telah ditetapkan terhadap } \\
\text { masing-masing } \\
\text { karakteristik CPIS. Responden } \\
\text { dengan nilai } \\
\text { total CPIS } \leq 6 \text { dikategorikan } \\
\text { tidak terdiagnosa } \\
\text { VAP dan responden dengan } \\
\text { nilai total CPIS }> \\
6 \text { dikategorikan VAP. }\end{array}$ & $\begin{array}{l}\text { Hasil menunjukkan bahwa } \\
\text { penerapan VAP bundle } \\
\text { berpengaruh dalam mencegah } \\
\text { terjadinya VAP. Hasil dari } \\
\text { penilaian total CPIS didapatkan } 4 \\
\text { dari } 6 \text { orang tidak terdiagnosa VAP } \\
\text { dan } 2 \text { orang terdiagnosa VAP. } \\
\text { Hasil } \\
\text { penelitian yang ada perlu didukung } \\
\text { dengan jumlah sampel yang lebih } \\
\text { besar dan perlu penilaian CPIS } \\
\text { secara berkelanjutan } \\
\text { untuk mengidentifi kasi VAP yang } \\
\text { disebabkan oleh bakteri onset } \\
\text { lambat khususnya pada pasien } \\
\text { yang terpasang ventilasi } \\
\text { mekanis dalam waku lama. }\end{array}$ & $\begin{array}{l}\text { Kejadian VAP setelah } \\
\text { penerapan Vap bundle yang telah } \\
\text { dilakukan } \\
\text { terhadap } 6 \text { responden didapatkan } 2 \\
\text { responden } \\
\text { terdiagnosa VAP dan } 4 \text { responden tidak } \\
\text { terdiagnosa VAP. Hal tersebut } \\
\text { diakibatkan } \\
\text { faktor-faktor antara lain penurunan } \\
\text { kesadaran, usia lanjut, albumin serum < } \\
2,2 \text {, } \\
\text { dan penurunan sistem imun responden } \\
\text { oleh } \\
\text { karena trauma dan usia lanjut. Faktor dari } \\
\text { petugas kesehatan sendiri yaitu } \\
\text { kepatuhan } \\
\text { dalam mencuci tangan masih didapatkan } \\
\text { kebiasaan tidak mencuci tangan sebelum } \\
\text { menyentuh pasien. Pada penelitian ini } \\
\text { sulit } \\
\text { untuk ditelusuri tingkat mortalitas yang } \\
\text { terjadi } \\
\text { pada responden apakah diakibatkan oleh } \\
\text { VAP atau akibat dari diagnosa primernya. }\end{array}$ \\
\hline
\end{tabular}

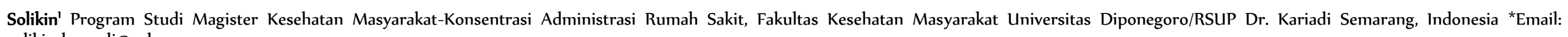
solikin_karyadi@yahoo.com

Matius Sakundarno Adi', Septo Pawelas Arso², Program Studi Magister Kesehatan Masyarakat, Fakultas Kesehatan Masyarakat Universitas Diponegoro, Semarang, Indonesia 
Pencegahan Kejadian Ventilator-Associated Pneumonia (VAP) dengan Kepatuhan Pelaksanaan Bundle: Literature review

\begin{tabular}{|c|c|c|c|c|c|c|}
\hline $\begin{array}{l}\text { Sadli, M. F., Tavianto, } \\
\text { D., \& Redjeki, I. S. } \\
\text { (2017). Gambaran } \\
\text { Pengetahuan Klinisi } \\
\text { Ruang Rawat Intensif } \\
\text { mengenai Ventilator } \\
\text { Associated } \\
\text { Pneumonia (VAP) } \\
\text { Bundle di Ruang } \\
\text { Rawat Intensif RSUP } \\
\text { Dr. Hasan Sadikin } \\
\text { Bandung. Jurnal } \\
\text { Anestesi } \\
\text { Perioperatif, 5(2), 85- } \\
\text { 93. }\end{array}$ & $\begin{array}{l}\text { - Tujuan penelitian } \\
\text { ini mengetahui } \\
\text { pengetahuan } \\
\text { dokter dan } \\
\text { perawat } \\
\text { mengenai VAPb } \\
\text { di ruang rawat } \\
\text { intensif RSUP Dr. } \\
\text { Hasan Sadikin } \\
\text { Bandung } \\
\text { - Penelitian ini } \\
\text { merupakan } \\
\text { penelitian } \\
\text { deskriptif } \\
\text { - dengan } \\
\text { pendekatan } \\
\text { potong lintang } \\
\text { mengenai } \\
\text { pengetahuan } \\
\text { VAPb di Ruang } \\
\text { Rawat Intensif } \\
\text { RSHS } \\
\text { Bandung.Total } \\
\text { sampling }\end{array}$ & 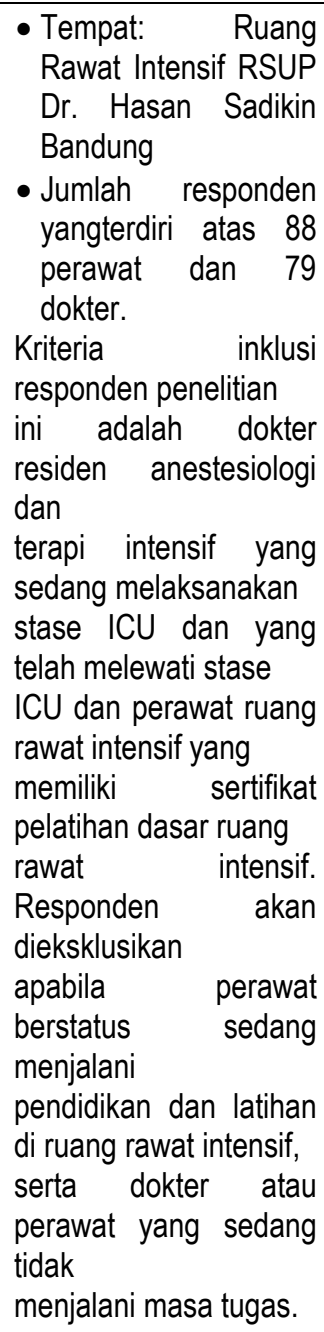 & $\begin{array}{l}\text { Karakteristik umum } \\
\text { perawat yang didata } \\
\text { berupa identitas } \\
\text { perawat, usia, jenis } \\
\text { kelamin, } \\
\text { status pendidikan, } \\
\text { lama kerja di ruang } \\
\text { rawat dan jenis } \\
\text { intensif, dan } \\
\text { ruang rawat. } \\
\text { Karakteristik } \\
\text { umum dokter yang } \\
\text { didata berupa } \\
\text { identitas joks } \\
\text { dokter, usia, jenis } \\
\text { kelamin, dan stase } \\
\text { ICU. }\end{array}$ & $\begin{array}{l}\text { Gambaran pengetahuan dokter } \\
\text { dan perawat } \\
\text { mengenai VAPb didapatkan } \\
\text { menggunakan } \\
\text { alat bantu kuesioner yang } \\
\text { terdiri atas } 20 \\
\text { pertanyaan pilihan ganda. }\end{array}$ & $\begin{array}{l}\text { Tingkat pengetahuan VAPb } \\
\text { diuji menggunakan } 20 \text { pertanyaan } \\
\text { kuesioner. Responden perawat } \\
\text { terbanyak berjenis kelamin } \\
\text { perempuan } \\
(74 \%) \text {, berusia } \geq 30 \text { tahun }(92 \%) \text {, } \\
\text { status pendidikan diploma III ( } 65 \%) \text {, } \\
\text { lama kerja }>5 \text { tahun ( } 76 \%) \text {, dan } \\
\text { bekerja di Intensive Care Unit (ICU) } \\
(32 \%) \text {. Responden dokter } \\
\text { terbanyak berjenis kelamin laki-laki } \\
(71 \%), \\
\text { berusia } \geq 30 \text { tahun }(83 \%) \text {, dan telah } \\
\text { menyelesaikan stase ICU (61\%) }\end{array}$ & $\begin{array}{l}\text { Nilai kuesioner perawat dan } \\
\text { dokter rata-rata berturut-turut } 73,63 \text { dan } \\
73,16 \text {. }\end{array}$ \\
\hline
\end{tabular}

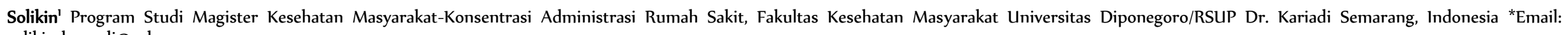
solikin_karyadi@yahoo.com

Matius Sakundarno Adi ${ }^{2}$, Septo Pawelas Arso², Program Studi Magister Kesehatan Masyarakat, Fakultas Kesehatan Masyarakat Universitas Diponegoro, Semarang, Indonesia 
Pencegahan Kejadian Ventilator-Associated Pneumonia (VAP) dengan Kepatuhan Pelaksanaan Bundle: Literature review

\begin{tabular}{|c|c|c|c|c|c|c|}
\hline $\begin{array}{l}\text { Tohirin, A., Saparwati, } \\
\text { M., \& Haryani, S. } \\
\text { (2019). Pengaruh oral } \\
\text { hygiene } \\
\text { menggunakan } \\
\text { hexadol gargle dalam } \\
\text { meminimalkan } \\
\text { kejadian ventilator } \\
\text { associated } \\
\text { pneumonia (VAP) di } \\
\text { ruang ICU RSUD } \\
\text { Tugurejo } \\
\text { Semarang. Jurnal } \\
\text { Keperawatan Dan } \\
\text { Kesehatan } \\
\text { Masyarakat Cendekia } \\
\text { Utama, 8(1), 9-16. }\end{array}$ & $\begin{array}{l}\text { - Tujuan penelitian } \\
\text { ini untuk } \\
\text { mengetahui } \\
\text { pengaruh } \\
\text { pelaksanaan oral } \\
\text { hygiene } \\
\text { menggunakan } \\
\text { antiseptic hexadol } \\
\text { gargle dalam } \\
\text { meminimalkan } \\
\text { kejadian } \\
\text { Ventilator } \\
\text { Associated } \\
\text { Pneumonia (VAP) } \\
\text { - Menggunakan } \\
\text { rancangan Pre- } \\
\text { Eksperimental } \\
\text { dengan desain } \\
\text { One Group } \\
\text { Pretest-posttest } \\
\text { Design } \\
\text { - Data pre-test } \\
\text { diambil pada hari } \\
\text { pertama } \\
\text { sedangkan data } \\
\text { post-test diambil } \\
\text { pada hari kelima } \\
\text { terpasang } \\
\text { ventilator. Data } \\
\text { dianalisis secara } \\
\text { univariat dan } \\
\text { bivariat } \\
\text { menggunakan uji } \\
\text { Wilcoxon. }\end{array}$ & $\begin{array}{l}\text { - Tempat: Ruang ICU } \\
\text { RSUD Tugurejo } \\
\text { - Pengambilan sampel } \\
\text { dilakukan secara } \\
\text { consecutive sampling } \\
\text { sejumlah } 15 \\
\text { responden Kriteria } \\
\text { inklusi sampel adalah } \\
\text { pasien usia } 25 \text { tahun } \\
\text { sampai } 60 \text { tahun, } \\
\text { menggunakan } \\
\text { antibiotik yang sama }\end{array}$ & $\begin{array}{l}\text { Alat penelitian } \\
\text { menggunakan SOP } \\
\text { oral } \\
\text { hygiene dan lembar } \\
\text { observasi Clinical } \\
\text { Pulmonary Infection } \\
\text { Score (CPIS). }\end{array}$ & $\begin{array}{l}\text { Penelitian menggunakan } \\
\text { rancangan Pre-Eksperimental } \\
\text { dengan desain One } \\
\text { Group Pretest-posttest } \\
\text { Design. }\end{array}$ & $\begin{array}{l}\text { Berdasarkan hasil penelitian, } \\
\text { didapatkan } p \\
\text { value adalah } 0,03(p<0,05), \\
\text { menunjukkan bahwa terdapat } \\
\text { perbedaan yang bermakna } \\
\text { antara kejadian ventilator } \\
\text { associated pneumonia (VAP) } \\
\text { sebelum dan sesudah oral } \\
\text { hygiene menggunakan hexadol } \\
\text { gargle }\end{array}$ & $\begin{array}{l}\text { Kesimpulan hasil penelitian ini } \\
\text { menunjukkan } \\
\text { pelaksanaan oral hygiene menggunakan } \\
\text { antiseptik Hexadol Gargle bisa } \\
\text { menurunkan } \\
\text { angka kejadian VAP. Oleh karena itu, } \\
\text { diharapkan kepada perawat yang } \\
\text { bertugas di } \\
\text { Ruang ICU RSUD Tugurejo untuk dapat } \\
\text { menerapkan penggunaan hexadol gargle } \\
\text { dalam } \\
\text { pelaksanaan oral hygiene sehari dua kali } \\
\text { pada pasien yang terpasang ventilator } \\
\text { mekanik } \\
\text { untuk mencegah VAP. }\end{array}$ \\
\hline
\end{tabular}

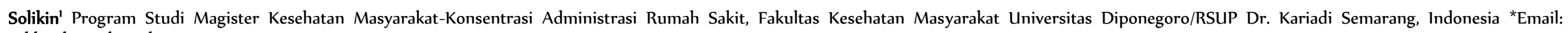
solikin_karyadi@yahoo.com

Matius Sakundarno Adi ${ }^{2}$, Septo Pawelas Arso², Program Studi Magister Kesehatan Masyarakat, Fakultas Kesehatan Masyarakat Universitas Diponegoro, Semarang, Indonesia 
Pencegahan Kejadian Ventilator-Associated Pneumonia (VAP) dengan Kepatuhan Pelaksanaan Bundle: Literature review

\begin{tabular}{|c|c|c|c|c|c|c|}
\hline $\begin{array}{l}\text { Debora, Y., Leksana, } \\
\text { E., \& Sutiyono, D. } \\
\text { (2012). Perbedaan } \\
\text { Jumlah Bakteri pada } \\
\text { Sistem Closed } \\
\text { Suction dan Sistem } \\
\text { Open Suction pada } \\
\text { Penderita dengan } \\
\text { Ventilator } \\
\text { Mekanik. JAl (Jurnal } \\
\text { Anestesiologi } \\
\text { Indonesia), 4(2), 73- } \\
\text { 83. }\end{array}$ & $\begin{array}{l}\text { - Mengetahui } \\
\text { efektivitas } \\
\text { penggunaan } \\
\text { closed suction } \\
\text { system } \\
\text { dibandingkan } \\
\text { dengan open } \\
\text { suction system } \\
\text { pada penderita } \\
\text { dengan ventilator } \\
\text { mekanik. } \\
\text { - Hasil analisa } \\
\text { disajikan bentuk } \\
\text { grafik Box Plot. } \\
\text { Analisis analitik } \\
\text { akan dilakukan } \\
\text { untuk menguji } \\
\text { hasil kultur } \\
\text { mikrobiologi pada } \\
\text { kedua kelompok } \\
\text { perlakuan dengan } \\
\text { uji non-parametrik } \\
\text { Mann Whitney, } \\
\text { Wilcoxon }\end{array}$ & $\begin{array}{l}\text { - Penelitian dilakukan } \\
\text { di : ICU RSUP Dr. } \\
\text { Kariadi Semarang } \\
\text { - Jumlah subyek } \\
\text { adalah } 30 \text { orang yang } \\
\text { dibagi menjadi } 2 \\
\text { kelompok (15 closed } \\
\text { suction system, } 15 \\
\text { open suction } \\
\text { system). Masing- } \\
\text { masing kelompok } \\
\text { diberikan oral } \\
\text { hygiene tiap } 12 \text { jam } \\
\text { selama } 48 \text { jam } \\
\text { - Kriteria inklusi: } \\
\text { Penderita dewasa } \\
\text { dengan ventilator } \\
\text { mekanik. }\end{array}$ & $\begin{array}{l}\text { Semua uji analitik } \\
\text { menggunakan } \\
a=0,05 . \text { Semua } \\
\text { perhitungan statistik } \\
\text { menggunakan } \\
\text { software Stastical } \\
\text { Pakckage for Social } \\
\text { Science SPSS } 15.0\end{array}$ & $\begin{array}{l}\text { Sampel adalah } 30 \text { orang dibagi } \\
\text { menjadi } 2 \text { kelompok secara } \\
\text { berurutan yaitu Pada kelompok } \\
1 \text { diberikan ventilasi mekanik } \\
\text { closed suction system dan } \\
\text { chlorhexidine } 0,2 \% \text { sebanyak } \\
25 \text { mL. Pada kelompok } 2 \\
\text { diberikan open suction system } \\
\text { dan chlorhexidine } 0,2 \% \\
\text { sebanyak } 25 \mathrm{~mL} \text {. Dilakukan } \\
\text { penyikatan dengan sikat gigi } \\
\text { pada } 4 \text { kuadran gigi (kanan } \\
\text { atas, kanan bawah, kiri atas, kiri } \\
\text { bawah) dan di antara kuadran } \\
\text { tersebut dilakukan semburan / } \\
\text { semprotan dengan pola teratur }\end{array}$ & $\begin{array}{l}\text { Hitung bakteria berbeda bermakna } \\
\text { pada kelompok I ( } p=0,001) \text { dan } \\
\text { berbeda bermakna pada kelompok } \\
\text { II ( } p=0,005) \text {. Analisis komparatif } \\
\text { selisih skor sebelum dan sesudah } \\
\text { perlakuan kedua kelompok berbeda } \\
\text { tidak bermakna }(p=0,008) \text {. }\end{array}$ & $\begin{array}{l}\text { Penggunaan closed suction system pada } \\
\text { pasien dengan ventilasi mekanik } \\
\text { mengurangi jumlah bakteri post-intervensi } \\
\text { secara signifikan, demikian halnya } \\
\text { dengan open suction system. Closed } \\
\text { suction system tidak lebih baik dalam } \\
\text { mengurangi jumlah bakteri pada } \\
\text { penelitian ini. }\end{array}$ \\
\hline
\end{tabular}

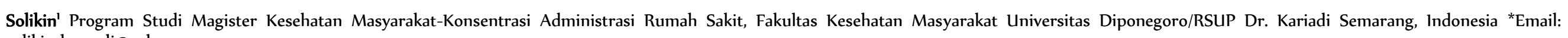
solikin_karyadi@yahoo.com

Matius Sakundarno Adi ${ }^{2}$, Septo Pawelas Arso², Program Studi Magister Kesehatan Masyarakat, Fakultas Kesehatan Masyarakat Universitas Diponegoro, Semarang, Indonesia 


\section{KAJIAN LITERATUR Penyebab}

Bakteria adalah penyebab yang paling sering dari VAP dan banyak infeksi adalah polimikrobial (The American Thoracic Society \& The Infectious Diseases Society of America, 2005). Mayoritas (56.9\%) infeksi pada pasien disebabkan oleh pathogen tunggal sedangkan pada pasien lain, infeksi disebabkan oleh dua atau tiga pathogen (Djordjevic et al., 2017). VAP umumnya disebabkan oleh basil gram negatif sebesar $92.5 \%$, seperti pseudomonas aeruginosa, Acinetobacter (Djordjevic et al., 2017) dan klepsiela pneumonia; atau oleh cocus gram positif, seperti staphilococus aureus yang kebanyakan merupakan meticilline resistant staphylococcus aureus (MRSA) (The American Thoracic Society \& The Infectious Diseases Society of America, 2005). Pasien dengan VAP onset lanjut lebih cenderung mengalami infeksi pathogen MDR dan mempunyai mortalitas lebih tinggi daripada pasien yang masih dalam onset awal (The American Thoracic Society \& The Infectious Diseases Society of America, 2005). Keberadaan pathogen MDR pada pasien yang menderita VAP berhubungan dengan peningkatan angka mortalitas (The American Thoracic Society \& The Infectious Diseases Society of America, 2005).

\section{Faktor Resiko}

Beberapa faktor diketahui dapat meningkatkan resiko VAP diantaranya intubasi dan reintubasi, nasograstric tube (NGT), komorbiditas baik yang terkait maupun tidak terkait dengan penurunan sistem imun, agen paralisis, aspirasi(Jaimes et al., 2007), posisi tidur (The American Thoracic Society \& The Infectious Diseases Society of America, 2005) dan durasi pemasangan selang ET (Lee et al., 2017). Insiden VAP juga meningkat pada bayi dengan berat badan rendah yang terpasang ventilator lebih dari dua hari (Lee et al., 2017). Pemasangan ET dapat memicu tumbuhnya biofilm sedangkan pemasangan NGT beresiko menyebabkan sinusitis yang kemudian berkembang menjadi VAP (The American Thoracic Society \& The Infectious Diseases Society of America, 2005). Posisi tidur supinasi dapat mendorong aspirasi pathogen dari orofaring (Alp \& Voss, 2006) kedalam saluran pernafasan bagian bawah (The American Thoracic Society \& The
Infectious Diseases Society of America, 2005) yang mana sangat berhubungan dengan pemberian nutrisi enteral (The American Thoracic Society \& The Infectious Diseases Society of America, 2005).

\section{Patogenesis}

Faktor patogenik utama yang berkontribusi dalam perkembangan VAP adalah pembentukan biofilm dalam selang ET dan aspirasi miko sekresi (Gunasekera \& Gratrix, 2016). Keberadaan selang ET dapat mengggangu reflek normal dari saluran pernafasan bagian atas dan mencegah batuk efektif sehingga dapat dengan cepat terkolonisasi oleh bakteri gram negative (Gunasekera \& Gratrix, 2016). Aspirasi pathogen dari orofaring (Alp \& Voss, 2006) atau kebocoran sekresi yang menandung bakteri di sekitar balon ET (The American Thoracic Society \& The Infectious Diseases Society of America, 2005) adalah rute utama masuknya bakteri penyebab VAP (Alp \& Voss, 2006; The American Thoracic Society \& The Infectious Diseases Society of America, 2005) kedalam saluran pernafasan bagian bawah (The American Thoracic Society \& The Infectious Diseases Society of America, 2005). Lambung dan sinus dapat menjadi reservoir potensial dari pathogen nosocomial yang dapat berkontribusi terhadap kolonisasi bakteri orofaring (The American Thoracic Society \& The Infectious Diseases Society of America, 2005). Aspirasi mikroorganisme pathogen pada saluran gastrointestinal dapat menyebabkan kejadian VAP (Alp \& Voss, 2006). Sejumlah faktor yang berhubungan dengan host dan treatmen juga merupakan pathogenesis penting dari VAP seperti beratnya penyakit dasar pasien, paparan terhadap antibiotik, dan paparan terhadap alat pernafasan invasive (The American Thoracic Society \& The Infectious Diseases Society of America, 2005).

\section{Pencegahan VAP dan profilaksis umum}

Sejumlah metode pencegahan kejadian VAP telah diteliti untuk mengurangi kejadian infeksi nosocomial ini namun konsensus terkait dengan strategi pencegahan yang tepat masih sedikit (Sebastian et al., 2012). Namun demikian, hasil penelitian merekomendasikan penerapan multimodal untuk mencegah kejadian VAP di rumah sakit (Leone et al., 2018) yang salah

Solikin' Program Studi Magister Kesehatan Masyarakat-Konsentrasi Administrasi Rumah Sakit, Fakultas Kesehatan Masyarakat Universitas Diponegoro/RSUP Dr. Kariadi Semarang, Indonesia *Email: solikin_karyadi@yahoo.com

Matius Sakundarno $\mathrm{Adi}^{2}$, Septo Pawelas Arso' ${ }^{2}$, Program Studi Magister Kesehatan Masyarakat, Fakultas Kesehatan Masyarakat Universitas Diponegoro, Semarang, Indonesia 
satunya berupa penerapan bundle pencegahan VAP yang mana sangat efektif menurunkan kejadian VAP di ruang perawatan intensive (Akdogan et al., 2017; Kao et al., 2019). Bundle merupakan sekumpulan intervensi berbasis ilmiah yang berhubungan dengan kondisi tertentu yang apabila diterapkan secara bersamaan dapat meningkatkan luaran pasien (Gunasekera \& Gratrix, 2016). Bundle ini menerapkan beberapa intervensi diantaranya penggunaan endotracheal tube subglottic secretion drainage (ETT-SD), monitoring tekanan balon ET sebesar 20-30 $\mathrm{cmH}_{2} \mathrm{O}$, profilaksis peptic ulcer, penggunaan orogastric feeding tube (OGT) daripada NGT sebagai alat bantu makan (Akdogan et al., 2017), oral hygiene dengan chlorhexidine 0.12-0.2\% (Akdogan et al., 2017; Hua et al., 2016), povidone iodine atau saline (Hua et al., 2016) elevasi bagian atas tempat tidur 30-400 (Akdogan et al., 2017; Kao et al., 2019; C.-H. Wang et al., 2015), evakuasi air pada sirkuit ventilator (Kao et al., 2019; C.-H. Wang et al., 2015), interupsi sedasi harian, pembersihan air dari sirkuit ventilator (C.-H. Wang et al., 2015) serta cuci tangan sebelum dan setelah tindakan (Kao et al., 2019).

Penerapan subglotik drainage terbukti dapat menurunkan kejadian VAP secara signifikan walaupun pengaruh terhadap kejadian mortalitas tidak signifikan (Akdogan et al., 2017). Sistem SD biasanya terdiri dari saluran aspirasi diatas balon selang ET dan sumber vakum untuk menyingkirkan sekresi dari area subglotik secara kontinu atau intermiten (Nseir et al., 2015). Sebuah meta analisis dari 13 RCT menunjukkan bahwa drainase sekresi subglotik efektif mengurangi tingkat VAP, mengurangi durasi ventilasi mekanik dan mengurangi length of stay di ICU (Nseir et al., 2015). Penggunaan aspirasi sekresi subgotik (Dodek et al., 2004) setiap 6 hingga 8 jam menggunakan tube yang tepat (Leone et al., 2018) direkomendasikan untuk pencegahan onset awal VAP (Leone et al., 2018). The American Thorasic Society dan the Infectious Disease Society of America merekomendasikan penggunaan aspirasi sekresi subglotis untuk mengurangi resiko onset awal VAP dan mengharuskan penggunaan intervensi ini apabila tersedia.

Penggunaan selang ET dapat memberikan akses antara rongga mulut dan saluran nafas bawah sehingga klinisi perlu memberikan perhatian terhadap balon ET untuk mencegah VAP sebagai akibat dari mikroaspirasi (Gunasekera \& Gratrix, 2016). The American Thorasic Society dan the Infectious Disease Society of America merekomendasikan monitoring balon ET pada tekanan $20 \mathrm{~cm} \mathrm{H}_{2} \mathrm{O}$ atau lebih untuk mencegah merembesnya bakteri pathogen sekitar balon ke saluran nafas bagian bawah. Balon ET yang kurang terkembang merupakan faktor resiko untuk terjadinya mikroaspirasi dari sekresi yang terkontaminasi dan VAP (Nseir et al., 2015).

Sebuah studi dengan meta analisis menunjukkan bahwa pengukuran rutin balon ET untuk mempertahankan inflasi balon yang adekuat bermanfaat untuk mengurangi resiko VAP (Nseir et al., 2015). Oleh kaena itu tenaga kesehatan direkomendasikan untuk melakukan verifikasi teratur terhadap tekanan balon ET (Leone et al., 2018).

Oral hygiene merupakan elemen penting dari pelayanan keperawatan dan sebuah pendekatan standar yang mempunyai potensi untuk meningkatkan outcome klinis VAP bagi pasien dengan kondisi kritis (Berry et al., 2011). Sebuah systematic review terhadap 18 randomised controlled trial (RCT) yang membandingkan penggunaan berbagai jenis larutan untuk oral care pada pasien terventilasi di ICU menunjukkan bahwa penggunaan chlorhexidine baik dalam bentuk cairan atau gel dibandingkan dengan placebo atau larutan standar dapat mengurangi resiko VAP pada pasien dengan penyakit kritis dari sekitar 24\% menjadi 18\% (Hua et al., 2016). Penggunaan oral care menggunakan chlorhexidine dapat mencegah kejadian VAP pada satu dari setiap 17 pasien yang terpasang ventilator selama lebih dari 48 jam di ruang perawatan intensive (Hua et al., 2016). Tidak ada perbedaan efektivitas antara oral care menggunakan kombinasi antiseptic dengan gosok gigi dibandingkan antiseptic saja terhadap penurunan kejadian $\operatorname{VAP}$ (Hua et al., 2016). Selain itu, penggunaan povidone iodine mouthwash lebih effektif dibandingkan penggunaan saline saja, dan penggunaan mouthwash menggunakan saline lebih efektif daripada penggunaan saline swab (Hua et al., 2016). Sebuah RCT dengan double blind yang membandingkan penggunaan chlorhexidine gluconate $0.2 \%$ swab empat kali sehari dengan saline terhadap 61 pasien yang

Solikin' Program Studi Magister Kesehatan Masyarakat-Konsentrasi Administrasi Rumah Sakit, Fakultas Kesehatan Masyarakat Universitas Diponegoro/RSUP Dr. Kariadi Semarang, Indonesia *Email: solikin_karyadi@yahoo.com

Matius Sakundarno $\mathrm{Adi}^{2}$, Septo Pawelas $\mathrm{Arso}^{2}$, Program Studi Magister Kesehatan Masyarakat, Fakultas Kesehatan Masyarakat Universitas Diponegoro, Semarang, Indonesia 
terpasang ventilator lebih dari 48 jam menunjukkan bahwa oral care dengan antiseptic ini dapat menurunkan resiko perkembangan VAP pada pasien yang terpasang yang terventilasi dan mendorong penggunaan oral care menggunakan antiseptic ini di ICU (Özçaka et al., 2012). Kejadian VAP turun secara signifikan pada kelompok chlorhexidice dibandingkan kelompok saline (41.4\% vs $68.8 \%$ dengan p 0.03 ) dalam 6.8 hari (Özçaka et al., 2012).

Pelepasan selang ET disarankan untuk mengurangi insiden infeksi nosocomial (Lee et al., 2017) Intubasi dan reintubasi harus dihindari jika memungkinkan karena dapat meningkatkan resiko VAP (The American Thoracic Society \& The Infectious Diseases Society of America, 2005). Pengurangan durasi intubasi dan ventilasi mekanik dapat dicapai dengan protokol untuk memperbaiki penggunaan sedasi dan mempercepat weaning (The American Thoracic Society \& The Infectious Diseases Society of America, 2005). Oleh karena itu protokol yang menggabungkan pengkajian harian mengenai kesiapan pasien untuk weaning dan interupsi sedasi harus ada di ICU (Strategy for the Control of Antimicrobial Resistance in Ireland \& Health Protection Surveillance Centre (Ireland), 2011). Ventilasi non-invasive harus digunakan ketika memungkinkan pada pasien tertentu dengan kegagalan pernafasan (The American Thoracic Society \& The Infectious Diseases Society of America, 2005). Intubasi orotracheal dan (OGT) tube lebih baik dari pada intubasi nasotracheal dan NGT untuk mencegah sinusitis nosocomial dan untuk mengurangi resiko VAP (The American Thoracic Society \& The Infectious Diseases Society of America, 2005).

Penerapan kewaspadaan standar harus menjadi strategi utama untuk pencegahan transmisi agen infeksius diantara pasien dan tenaga kesehatan dimana cuci tangan menjadi bagian rutin dalam perawatan pasien yang terpasang ventilator mekanik (Strategy for the Control of Antimicrobial Resistance in Ireland \& Health Protection Surveillance Centre (Ireland), 2011). Tangan harus didekontaminasi dengan tepat menggunakan air dan sabun atau hand rub alkohol sebelum dan setelah kontak langsung dengan pasien, setelah setiap tindakan yang berpotensi menyebabkan kontaminasi tangan dan setelah pelepasan sarung tangan (Strategy for the
Control of Antimicrobial Resistance in Ireland \& Health Protection Surveillance Centre (Ireland), 2011). Sebuah studi dengan meta analisis terhadap 6 RCT menunjukkan bahwa hand hygiene mempunyai pengaruh terhadap pencegahan kejadian VAP dan berhubungan dengan morbiditas VAP yang lebih rendah (Ma et al., 2014). Keenam studi tersebut melaporkan bahwa cuci tangan menurunkan resiko vap dengan rik reduction berkisar antara $29.8 \%$ hingga $65.5 \%$ dengan nilain mean risk reduction $50.6 \%$ (Ma et al., 2014). Kepatuhan terhadap hand hygiene harus dimonitor secara teratur untuk memastikan kepatuhan dan umpan balik harus diberikan kepada staff kesehatan(Strategy for the Control of Antimicrobial Resistance in Ireland \& Health Protection Surveillance Centre (Ireland), 2011).

Posisi supinasi pasien dapat menyebabkan aspirasi yang mana dapat dicegah dengan posisi head up (The American Thoracic Society \& The Infectious Diseases Society of America, 2005). Sebuah systematic review yang membandingkan posisi head up dengan supinasi untuk pencegahan VAP pada pasien yang terpasang ventilator pada 8 RCT yang melibatkan sejumlah 759 partisipan menunjukkan bahwa posisi head up 30 derajat atau lebih dapat menurunkan VAP dibandingkan posisi supinasi 0 derajat hingga 10 derajat ( $L$. Wang et al., 2016). VAP pada pasien dengan posisi supinasi sangat terkait dengan pemberian nutrisi enteral, sehingga pasien yang terintubasi harus diposisikan head up terutama pada saat pemberian nutrisi enteral (The American Thoracic Society \& The Infectious Diseases Society of America, 2005). Walaupun pemberian terapi enteral dini baik untuk pasien kritis, refluk dan aspitasi isi lambung adalah penyebab utama VAP (Gunasekera \& Gratrix, 2016).

The American Thorasic Society dan the Infectious Disease Society of America merekomendasikan profilaksis umum untuk mencegah kejadian VAP yang meliputi surveilen infeksi di ICU dan tindakan kontrol infeksi yang efektif (The American Thoracic Society \& The Infectious Diseases Society of America, 2005). Tindakan kontrol infeksi meliputi edukasi staff, kepatuhan terhadap disinfeksi tangan menggunakan cairan berbasis alcohol, dan isolasi untuk mengurangi infeksi silang dengan pathogen MDR harus digunakan secara rutin (The American

Solikin' Program Studi Magister Kesehatan Masyarakat-Konsentrasi Administrasi Rumah Sakit, Fakultas Kesehatan Masyarakat Universitas Diponegoro/RSUP Dr. Kariadi Semarang, Indonesia *Email: solikin_karyadi@yahoo.com

Matius Sakundarno $\mathrm{Adi}^{2}$, Septo Pawelas $\mathrm{Arso}^{2}$, Program Studi Magister Kesehatan Masyarakat, Fakultas Kesehatan Masyarakat Universitas Diponegoro, Semarang, Indonesia 
Thoracic Society \& The Infectious Diseases Society of America, 2005). Surveilen untuk mengidentifikasi dan mengkuantifikasi endemi dan patogen MDR baru, persiapan data untuk kontrol infeksi dan untuk mengarahkan terapi antimikrobial yang tepat (The American Thoracic Society \& The Infectious Diseases Society of America, 2005).

\section{Deteksi Dini dan Diagnosis}

Diagnosis yang tepat waktu diperlukan untuk memberikan antibiotik yang tepat untuk meningkatkan luaran pasien (Miller, 2018). Sampai saat ini, belum terdapat tes tunggal (Miller, 2018) serta kriteria standar emas untuk mendiagnosis VAP (Kalanuria et al., 2014). Namun demikian, The American Thorasic Society dan the Infectious Disease Society of America telah memberikan beberapa poin penting dan rekomendasi terkait strategi diagnosis yang bertujuan untuk mengidentifikasi pasien dengan infeksi paru untuk memastikan pengumpulan sampel kultur yang tepat, untuk mendorong penggunaan terapi antibiotik dini yang efektif, dan untuk mengidentifikasi pasien yang mempunyai infeksi di luar paru. Riwayat medis komprehensif semua pasien harus dikaji dan pemeriksaan fisik dilakukan untuk menentukan beratnya infeksi, untuk mengeksklusi sumber infeksi potensial dan untuk adanya kondisi spesifik yang dapat mempengaruhi pathogen penyebab (The American Thoracic Society \& The Infectious Diseases Society of America, 2005). Semua pasien harus mempunyai radiografi paru (Kalanuria et al., 2014) untuk membantu menentukan beratnya pneumonia, misal multilobus atau tidak, dan adanya komplikasi, misal efusi atau kapitasi (The American Thoracic Society \& The Infectious Diseases Society of America, 2005). Saturasi oksigen arteri harus diukur pada semua pasien untuk menentukan perlunya terapi oksigen dan pemeriksaan analisa gas darah harus dilakukan jika ada kekhawatiran terkait asidosis metabolik atau respiratorik (The American Thoracic Society \& The Infectious Diseases Society of America, 2005).

Semua pasien yang menunjukkan tanda-tanda VAP harus dilakukan pemeriksaan gram, pewarnaan, kultur dan sensitivitas terhadap sekresi saluran pernafasan (Kalanuria et al., 2014) serta kultur darah, untuk mengetahui keberadaan pneumonia atau infeksi ekstra paru (The American
Thoracic Society \& The Infectious Diseases Society of America, 2005). Kultur saluran nafas bawah perlu dilakukan kepada semua pasien sebelum pemberian (The American Thoracic Society \& The Infectious Diseases Society of America, 2005). Selain itu, data hasil kultur juga dapat digunakan untuk menyesuaikan perubahan terapi antibiotik (Kalanuria et al., 2014). Kultur saluran bawah dapat dilakukan dengan atau tanpa bronchoscopy dan dikultur secara kuantitatif atau semikuantitatif (The American Thoracic Society \& The Infectious Diseases Society of America, 2005). Namun demikian, pemeriksaan kultur tidak boleh menunda pemberian antibiotik pada pasien dengan penyakit kritis (The American Thoracic Society \& The Infectious Diseases Society of America, 2005). Hasil kultur sekresi saluran pernafasan yang steril dimana tidak ada antibiotik baru dalam 72 jam terahir menunjukkan ketiadaan pneumonia karena infeksi bakteri, tapi infeksi karena virus atau Legionella masih mungkin (The American Thoracic Society \& The Infectious Diseases Society of America, 2005). Hasil kultur yang negatif tersebut dapat digunakan sebagai dasar untuk menghentikan terapi antibiotik (The American Thoracic Society \& The Infectious Diseases Society of America, 2005).

\section{Pemberian Antibiotik}

Pemilihan terapi antibiotik awal pada pasien dengan VAP sangat penting dikarenakan treatmen antimicrobial awal yang tidak tepat berhubungan dengan mortalitas yang lebih tinggi dan length of stay yang lebih lama di ICU (Arthur et al., 2016). Terapi antibiotik spectrum luas awal yang tepat harus diberikan dengan dosis yang adekuat untuk memaksimalkan kemanjuran antimicrobial (The American Thoracic Society \& The Infectious Diseases Society of America, 2005). Berbagai studi menunjukkan pentingnya pemberian dini antibiotik yang tepat untuk meningkatkan prognosis (Alp \& Voss, 2006). Sebuah regimen terapi empiris harus menyertakan kombinasi dari dari agen antibiotik berbeda dari terapi antibiotik yang sedang pasien sedang terima pada saat itu (The American Thoracic Society \& The Infectious Diseases Society of America, 2005). Untuk memulai terapi antibiotik empiris yang tepat, klinisi perlu untuk mengetahui agen penyebab VAP yang mendominasi disetiap seting klinik atau ICU dan

Solikin' Program Studi Magister Kesehatan Masyarakat-Konsentrasi Administrasi Rumah Sakit, Fakultas Kesehatan Masyarakat Universitas Diponegoro/RSUP Dr. Kariadi Semarang, Indonesia *Email: solikin_karyadi@yahoo.com

Matius Sakundarno $\mathrm{Adi}^{2}$, Septo Pawelas Arso', Program Studi Magister Kesehatan Masyarakat, Fakultas Kesehatan Masyarakat Universitas Diponegoro, Semarang, Indonesia 
pola sensitivitas terhadap antibiotiknya (Djordjevic et al., 2017). Terapi kombinasi untuk patogen spesifik harus digunakan dengan bijaksana dalam mengobati pneumonia, dan pertimbangan harus dilakukan untuk terapi aminoglikosida durasi pendek (5 hari) (The American Thoracic Society \& The Infectious Diseases Society of America, 2005). Kombinasi terapi antibiotik dapat meningkatkan harapan hidup dan respon klinik pasien dengan infeksi berat dan mengancam jiwa terutama pasien yang mengalami shok sepsis (Kumar et al., 2010). Terapi antibiotik durasi pendek (7-8 hari) direkomendasikan untuk pasien VAP tanpa komplikasi yang telah menerima terapi yang tepat pada awalnya dan mempunyai respon klinik yang baik dengan tanpa ada bukti infeksi basil gram negatif non fermentasi (The American Thoracic Society \& The Infectious Diseases Society of America, 2005). Klinisi harus mempertimbangkan untuk melakukan deeskalasi antibiotik berdasarkan data hasil kultur dan respon klinik pasien (The American Thoracic Society \& The Infectious Diseases Society of America, 2005). Penggunaan antibiotik yang bijak sangat diperlukan untuk mencegah perkembangan organisme MDR yang dapat merugikan pasien (Miller, 2018).

\section{SIMPULAN}

Penggunaan ventilator mekanik pada pasien kritis dapat menimbulkan infeksi jaringan parenkim paru atau VAP yang merupakan penyebab utama morbiditas dan mortalitas di ICU serta meningkatkan biaya di rumah sakit. Pencegahan kejadian VAP di rumah sakit menggunakan intervensi multimodal, yang mana salah satunya berupa penerapan bundle pencegahan VAP, dapat dengan efektif menurunkan kejadian VAP di rumah sakit. The American Thorasic Society dan the Infectious Disease Society of America telah memberikan beberapa poin penting dan rekomendasi terkait strategi diagnosis dan deteksi dini VAP yang sangat bermanfaat untuk dijadikan panduan bagi tenaga kesehatan di instansi kesehatan. Pemeriksasan kultur saluran nafas bawah perlu dilakukan kepada semua pasien sebelum pemberian terapi antibiotik dengan catatan tidak boleh menunda pemberian terapi antibiotik pada pasien kritis. Hasil kultur yang negatif dapat digunakan untuk menghentikan terapi antibiotik pada pasien yang dilakukan kultur tanpa perubahan antibiotik dalam 72 jam terahir. Terapi antibiotik untuk VAP di ICU harus berdasarkan panduan berbasis ilmiah dan data empiris tentang sensitivitas antibiotik dari mikroorganism setempat, dimana mayoritas infeksi VAP disebabkan oleh basil gram negatif seperti pseudomonas aeruginosa dan Acinetobacter. Terapi dini antibiotik spektum luas dengan dosis yang tepat dapat memaksimalkan kemanjuran antibiotik dan luaran pasien VAP di ICU. Kombinasi antibiotik harus digunakan dengan bijaksana untuk mengobati VAP karena pathogen tertentu untuk meningkatkan harapan hidup pasien dengan infeksi berat terutama yang mengalami shok sepsis. Pasien dengan yang yang telah menerima terapi antibiotik dini dengan tepat, tidak menunjukkan komplikasi dan tidak ada bukti mengalami infeksi karena basil gram negatif dapat diberikan antibiotik dengan durasi singkat yaitu 7 sampai 8 hari. Tim kesehatan harus mempertimbangkan perlunya deeskalasi antibiotik berdasarkan hasil kultur dan respon klinik pasien.

\section{DAFTAR PUSTAKA}

Akdogan, O., Ersoy, Y., Kuzucu, C., Gedik, E., Togal, T., \& Yetkin, F. (2017). Assessment of the effectiveness of a ventilator associated pneumonia prevention bundle that contains endotracheal tube with subglottic drainage and cuff pressure monitorization. The Brazilian Journal of Infectious Diseases, 21(3), 276-281. https://doi.org/10.1016/j.bjid.2017.01.002

Alp, E., \& Voss, A. (2006). Ventilator associated pneumonia and infection control. Annals of Clinical Microbiology and Antimicrobials, 5, 7. https://doi.org/10.1186/1476-0711-5-7

Arthur, L. E., Kizor, R. S., Selim, A. G., van Driel, M. L., \& Seoane, L. (2016). Antibiotics for ventilator-associated pneumonia. The Cochrane Database of Systematic Reviews, 10, CD004267.

https://doi.org/10.1002/14651858.CD004267.pu b4

Berry, A. M., Davidson, P. M., Nicholson, L., Pasqualotto, C., \& Rolls, K. (2011). Consensus based clinical guideline for oral hygiene in the

Solikin' Program Studi Magister Kesehatan Masyarakat-Konsentrasi Administrasi Rumah Sakit, Fakultas Kesehatan Masyarakat Universitas Diponegoro/RSUP Dr. Kariadi Semarang, Indonesia *Email: solikin_karyadi@yahoo.com

Matius Sakundarno $\mathrm{Adi}^{2}$, Septo Pawelas Arso' ${ }^{2}$, Program Studi Magister Kesehatan Masyarakat, Fakultas Kesehatan Masyarakat Universitas Diponegoro, Semarang, Indonesia 
critically ill. Intensive and Critical Care Nursing, 27(4), 180-185. https://doi.org/10.1016/j.iccn.2011.04.005

Djordjevic, Z. M., Folic, M. M., \& Jankovic, S. M. (2017). Distribution and antibiotic susceptibility of pathogens isolated from adults with hospitalacquired and ventilator-associated pneumonia in intensive care unit. Journal of Infection and Public Health, 10(6), 740-744. https://doi.org/10.1016/j.jiph.2016.11.016

Dodek, P., Keenan, S., Cook, D., Heyland, D., Jacka, M., Hand, L., Muscedere, J., Foster, D., Mehta, N., Hall, R., Brun-Buisson, C., \& for the Canadian Critical Care Trials Group and the Canadian Critical Care Society. (2004). Evidence-Based Clinical Practice Guideline for the Prevention of Ventilator-Associated Pneumonia. Annals of Internal Medicine, 141(4), 305. https://doi.org/10.7326/0003-4819141-4-200408170-00011

Gunasekera, P., \& Gratrix, A. (2016). Ventilatorassociated pneumonia. BJA Education, 16(6), 198-202. https://doi.org/10.1093/bjaed/mkv046

Hua, F., Xie, H., Worthington, H. V., Furness, S., Zhang, Q., \& Li, C. (2016). Oral hygiene care for critically ill patients to prevent ventilatorassociated pneumonia. Cochrane Database of Systematic Reviews. https://doi.org/10.1002/14651858.CD008367.pu b3

Jaimes, F., De La Rosa, G., Gómez, E., Múnera, P., Ramírez, J., \& Castrillón, S. (2007). Incidence and risk factors for ventilatorassociated pneumonia in a developing country: Where is the difference? Respiratory Medicine, 101(4), https://doi.org/10.1016/j.rmed.2006.08.008

Kalanuria, A. A., Zai, W., \& Mirski, M. (2014). Ventilator-associated pneumonia in the ICU. Critical Care, 8.

Kao, C.-C., Chiang, H.-T., Chen, C.-Y., Hung, C.T., Chen, Y.-C., Su, L.-H., Shi, Z.-Y., Liu, J.-W.,
Liu, C.-P., Chuang, Y.-C., Ko, W.-C., Chen, Y.H., Tseng, S.-H., Lee, C.-M., Lu, M.-C., \& Hsueh, P.-R. (2019). National bundle care program implementation to reduce ventilatorassociated pneumonia in intensive care units in Taiwan. Journal of Microbiology, Immunology and Infection, 52(4), 592-597. https://doi.org/10.1016/j.jmii.2017.11.001

Kumar, A., Safdar, N., Kethireddy, S., \& Chateau, D. (2010). A survival benefit of combination antibiotic therapy for serious infections associated with sepsis and septic shock is contingent only on the risk of death: A metaanalytic/meta-regression study. Critical Care Medicine, 38(8), 1651-1664. https://doi.org/10.1097/CCM.0b013e3181e96b9 1

Lee, P.-L., Lee, W.-T., \& Chen, H.-L. (2017). Ventilator-Associated Pneumonia in Low Birth Weight Neonates at a Neonatal Intensive Care Unit: A Retrospective Observational Study. Pediatrics \& Neonatology, 58(1), 16-21. https://doi.org/10.1016/j.pedneo.2015.10.014

Leone, M., Bouadma, L., Bouhemad, B., Brissaud, O., Dauger, S., Gibot, S., Hraiech, S., Jung, B., Kipnis, E., Launey, Y., Luyt, C.-E., Margetis, D., Michel, F., Mokart, D., Montravers, P., Monsel, A., Nseir, S., Pugin, J., Roquilly, A., ... Chanques, G. (2018). Hospital-acquired pneumonia in ICU. Anaesthesia Critical Care \& Pain Medicine, 37(1), 83-98. https://doi.org/10.1016/j.accpm.2017.11.006

Ma, S., Liu, S., Huang, L., Xu, C., Liu, W., \& Huang, Y. (2014). A meta analysis of the effect of enhanced hand hygiene on the morbidity of ventilator-associated pneumonia. Zhonghua Wei Zhong Bing Ji Jiu Yi Xue, 26(5), 304-308. https://doi.org/10.3760/cma.j.issn.20954352.2014.05.004

Miller, D. F. (2018). Ventilator-Associated Pneumonia. Intensive Care, 6.

Nseir, S., Lorente, L., Ferrer, M., Rouzé, A., Gonzalez, O., Bassi, G. L., Duhamel, A., \& Torres, A. (2015). Continuous control of

Solikin' Program Studi Magister Kesehatan Masyarakat-Konsentrasi Administrasi Rumah Sakit, Fakultas Kesehatan Masyarakat Universitas Diponegoro/RSUP Dr. Kariadi Semarang, Indonesia *Email: solikin_karyadi@yahoo.com

Matius Sakundarno $\mathbf{A d i}^{2}$, Septo Pawelas Arso', Program Studi Magister Kesehatan Masyarakat, Fakultas Kesehatan Masyarakat Universitas Diponegoro, Semarang, Indonesia 
Pencegahan Kejadian Ventilator-Associated Pneumonia (VAP) dengan Kepatuhan Pelaksanaan Bundle: Literature review

tracheal cuff pressure for VAP prevention: A collaborative meta-analysis of individual participant data. Annals of Intensive Care, 5. https://doi.org/10.1186/s13613-015-0087-3

Özçaka, Ö., Başoğlu, O. K., Buduneli, N., Taşbakan, M. S., Bacakoğlu, F., \& Kinane, D. F. (2012). Chlorhexidine decreases the risk of ventilator-associated pneumonia in intensive care unit patients: A randomized clinical trial. Journal of Periodontal Research, 47(5), 584$592 . \quad$ https://doi.org/10.1111/j.16000765.2012.01470.x

Sebastian, M., Lodha, R., Kapil, A., \& Kabra, S. (2012). Oral mucosal decontamination with chlorhexidine for the prevention of ventilatorassociated pneumonia in children-A randomized, controlled trial. Pediatric Critical Care Medicine, 13(5), 305-310.

Silva, A. R. A. da, Silva, T. C. da, Bom, G. J. T., Vasconcelos, R. M. B., \& Junior, R. S. (2018). Ventilator-associated pneumonia agents in Brazilian Neonatal Intensive Care Units - a systematic review. The Brazilian Journal of Infectious Diseases, 22(4), 338-344. https://doi.org/10.1016/j.bjid.2018.06.002

Strategy for the Control of Antimicrobial Resistance in Ireland, \& Health Protection Surveillance Centre (Ireland). (2011). Guidelines for the prevention of ventilator-associated pneumonia in adults in Ireland. Health Protection Surveillance Centre.
Tablan, O., Anderson, L., Besser, R., Bridges, C., \& Hajjeh, R. (2004). Guidelines for Preventing Health-Care-Associated Pneumonia, 2003: Recommendations of $\mathrm{CDC}$ and the Healthcare Infection Control Practices Advisory Committee (pp. 1-179) [Data set]. American Psychological Association.

https://doi.org/10.1037/e548652006-001

The American Thoracic Society, \& The Infectious Diseases Society of America. (2005). Guidelines for the Management of Adults with Hospital-acquired, Ventilator-associated, and Healthcare-associated Pneumonia. American Journal of Respiratory and Critical Care Medicine, 171(4), 388-416. https://doi.org/10.1164/rccm.200405-644ST

Wang, C.-H., Ho, Y.-H., Jiang, H.-L., Wang, L.-S., Cheng, L.-C., Ho, G.-J., Chung, H.-C., Huang, X.-H., \& Xu, Y.-P. (2015). Efficacy of ventilatorassociated pneumonia bundle in the surgical intensive care unit. Journal of Microbiology, Immunology and Infection, 48(2), S162. https://doi.org/10.1016/j.jmii.2015.02.565

Wang, L., Li, X., Yang, Z., Tang, X., Yuan, Q., Deng, L., \& Sun, X. (2016). Head bed elevation versus flat bed for preventing ventilatorassociated pneumonia (VAP) in adults requiring mechanical ventilation. Cochrane. https://doi.org/10.1002/14651858.CD009946.pu b2

Solikin' Program Studi Magister Kesehatan Masyarakat-Konsentrasi Administrasi Rumah Sakit, Fakultas Kesehatan Masyarakat Universitas Diponegoro/RSUP Dr. Kariadi Semarang, Indonesia *Email: solikin_karyadi@yahoo.com

Matius Sakundarno $\mathrm{Adi}^{2}$, Septo Pawelas Arso ${ }^{2}$, Program Studi Magister Kesehatan Masyarakat, Fakultas Kesehatan Masyarakat Universitas Diponegoro, Semarang, Indonesia 